\title{
HOW PARTICIPATION SHAPES LOCAL DEVELOPMENT
}

\author{
Muhadjir Darwin \\ Faculty of Social and Political Sciences, Universitas Gadjah Mada \\ Correspondence: Muhadjir Darwin (e-mail: d_muhadjir@yahoo.com)
}

\begin{abstract}
This article elaborates citizens' participation in shaping local development in the Indonesian context. The main question is how to make local development more participatory as a guarantee that citizens' rights are fully realized. In that respects, social accountability is a key that should be improved from supply and demand sides simultaneously. From the supply side, there is a need to reform local governance, in order to improve the quality of local regulations, local planning, local budgeting, and local public service provision. While from the demand side, there is a need to empower local citizens so that they are engaged in five forms or local development efforts: local regulation formulation, local development planning, local budgeting, community driven development, and public service provision.
\end{abstract}

Keywords: local development, social accountability, local citizens

State should encourage popular participation in all spheres as an important factor in development and in the full realization of all human rights.

(United Nations, The Declaration on the Right to Development [2000], the second clause of Article 8)

\section{Introduction}

The success of national development lies on the effectiveness of local development since most implementation of national development policies are in the hand of local governments. Likewise, in this current era of decentralization local governments play strategic roles not only as implementers of policies designed by the central government, but also as policy makers on local development. The policies they make should be in accordance with national development goals but at the same time, it ought to be in line with the aspirations of their citizens.
In the context of fulfilling the people aspiration, local developments must be participatory. People are not object but subject of development. Concurrently the meaning of their participation should not be reduced as a legitimating factor of top-down government decisions but as strategic stakeholders in all stages of government planning and public policy processes. Indonesia has ratified the United Nations' Declaration of the Right to Development (2000); an article 8 states "State should encourage popular participation in all spheres as an important factor in development and in the full realization of all human rights". 
Indonesia has also ratified Millennium Development Goals as a standard of the national development achievement. This global commitment emphasizes a special concern on poverty alleviation for seven out of eight goals address poverty related issues. In the same time it highlights MDGs requirement for citizen participation, especially the poor, in development processes. "Empowering poor people and marginalized communities, improving local governance, providing adequate public infrastructure and services, and enabling dynamic, equitable private sector growth are all required to meet the MDGs. These results cannot be achieved by fiat from above; they must be produced by effort from below supported by enabling policies and partnerships" (Helling, et.al., 2005: i).

In addition, Indonesian Government has also ratified National Poverty Alleviation Strategies (SNPK) which adopted the rightbased approach of development stated in the United Nations' Declaration of the Right to Development. The SNPK mentions that "The State respect, protect, and fulfill poor people rights, men and women" (Bappenas, 2005: 123) and "Poverty alleviation is carried out with the active involvement of all parties, including the poor, men as well as women" (Menko Kesra, 2005: 125 and Darwin, 2005: 56).

\section{Why Participation?}

First, we are now in time in which the waves of democracy, decentralization and governance flow to all parts of the globe almost inescapably. In the last two decades, Indonesia has been a part of this global movement. It seems difficult, if not impossible, to return the clock back to the obsolete authoritarian and centralist system. There is a strong argument to maintain it. Decentralization and democratic local governance have a greater vitality to achieve the social welfare; one of them is through delivering accountable and responsive public services. Decentralization can effectively shortens the "long route" of accountability by creating opportunities for more meaningful and more effective contact between public officials and citizen influence over public management (UNDP, 2004).

The key term, which identifies such type of promising system, is citizen participation. There will be no real democracy, effective decentralization and good governance without real people participation. With no genuine participation democracy is artificial. In the absence of people participation, decentralization only moves centralization and corruption from the center to the local areas. Good governance requires several key

\section{Box 1 Four Types of States' Obligation to People}

Respect: The state should not to interfere; it has to respect the political rights of its people, also to respect property rights to enable people to provide for themselves.

Protect: The state has to stop other people abusing the rights of their fellow citizens-by enacting and enforcing appropriate legislation.

Facilitate: The state should do in a more positive form of intervention-such as building infrastructure, running public health campaigns-so as to improve people's capacity to raise their own standards of human development.

Fulfill: If all else fails, in the case of some people, the elderly, the disabled, or the disadvantageous groups are genuinely unable to meet their own needs, then the ultimately the government should step in as the provider of last resort.

Source: Stalker \& Mishra, 2003: 9 


\section{Box 2 Key Attributes of Good Governance}

1. Full protection and promotion of civil, political, economic, social and cultural rights for all

2. Practices of democracy and respect for human rights, including minority rights

3. Inclusive political processes, allowing genuine participation by all citizens in all our countries

4. Freedom of the media to perform their essential role and the right of public to have access to information.

Source: DESA, 2005: 5

attributes; one of them is inclusive political process, which allow all citizens to participate.

Second, participation is needed to make development process more accountable. Accountability is the synthesis of two concepts: answerability- "the tight to receive information and the corresponding obligations to release details"-and enforcement- "the idea that accounting actors do not just 'call into question' but also 'eventually punish' improper behavior (Schedler, 1999: 13). In other words $A$ is accountable to $B$ if $B$ can (1) know A's behavior, and (2) exert pressure on $A$ to influence that behavior (Hale, 2008: 76). The answerability is a matter of transparency-the availability of information for the citizens to access. Only when citizens have capacity and willingness to receive information from the governments and use this information to call into question the public officials' wrongdoing or to punish their improper behavior, the government will be accountable.

In other words, using their right to participate, people are able to control local government budget such as DAU, DAK, or revenue sharing to make utilization of the funds go to the programs which give real benefits to local people, particularly the poor. Participation is also necessary in public service deliveries. To improve the quality of public services, people can provide policy makers with a variety of ideas, perspectives and suggestions than traditional policy advice can offer. Participation is therefore have a practical value; it improves the performance of key public services by shaping betterinformed decisions and ensuring that limited resources are used to meet service users' priorities. Participation can also improve communication and building trust, reduce conflict and discord, and smooth the process of policy implementation freedom of the media to perform their essential role and the right of public to have access to information.

Third, participation is needed because this is the only way for governments to gain legitimacy when the trust in governments is low. This is particularly important in the context of an increasing number of devolved service agencies and partnerships, whose indirect relationships with a local government have led to accusations of 'democratic deficit'. Here participation may be seen as a way to help draw a balance between the desire of devoted agencies for autonomy and the need for them to maintain their credibility and legitimacy with the public for managing public services (Simmons and Bichal, 2005: 262).

In many developing countries governments fail to deliver key essential services to their citizens because of problems such as misallocation of resources, leakages/ corruption, weak incentives or lack of articulated demand. Similarly, governments often formulate policies in a discretionary and non-transparent manner that goes against the interests and actual priorities of the poor. These problems are perpetuated because the three groups of actors in public policy and service delivery chain-policy makers, service providers and citizens-have different (sometimes conflicting) goals and incentives, compounded by information asymmetries and lack of communication. By enhancing 
the availability of information, strengthening citizen voice, promoting dialogue and consultation between the three groups of actors and creating incentives for improved performances, social accountability can go a long way toward improving the effectiveness of service delivery and making public decision making more transparent, participatory and pro-poor. Since poor people are most reliant on government services and least equipped to hold government officials to account, they have most to gain from social accountability initiatives (Malena, et.al., 2004: 4).

Nevertheless, participation is a nice word that anyone likes to say. Even authoritarian regimes often use the term, not so much to empower people or to meet people's demand but rather to gain public acceptance or to obtain political legitimacy. The Soeharto's regime always argued about the importance of people participation in development. However, what they really wanted was not genuine citizen involvement but people mobilization to support the ruler's political agenda. Six times of general election during 30 years of the New Order Era, more than $90 \%$ of eligible citizens voted, yet this high participation level did not represent a real participation since the government socialized the concept of voting as people obligation rather than right.

Participation is not socialization in which the government socializes their top-down policies to get people acceptance and support, sometimes coercively. Participation is the genuine involvement of people, regardless of their political affiliation, gender identities, economic and social status in the whole policy processes or in the provision of public services. In order to get genuine people participation, government should acknowledge, respect, facilitate, and fulfill the people rights to express their will.

In the current democratic system, elites or certain social groups sometimes use the term of participation for the political agendas, which are against the values of democracy, pluralism, freedom, transparency, or tolerance.
This happens when a religious radical group went to the street to support the bill on antipornography, the bill which basically limits the freedom of people to express, or when such a group acted violently to the other mass who demonstrate peacefully in the public place to demand government to protect people freedom to believe. ${ }^{1}$

Likewise, general elections (pemilu), president elections (pilpres), or local head elections (pilkada) political candidates often brought their fanatic followers (sometimes using money politics) into violent and bloody conflicts with their opponent fanatic followers that keeps the democratic political election far from peace and fail to make people wiser by acknowledging difference and accepting lose. This violent and bloody election happens in many elections in the country; the extreme cases were in Poso, Central Sulawesi, also in Maluku and North Maluku. Likewise, the decentralization law which allows local areas to form new provinces or districts, often used by local politicians to mobilize local residents to gain approval of their pemekaran (expansion) proposal in the sake of their own interests, sometimes through bloody violence as happened in the case of Tapanuli, North Sumatra.

This is not participation we expect to extend. Rather, we have to develop people participation that admires the values of democracy, pluralism, humanism, and inclusiveness. The success of participatory local development does not rely on whether or not we are able to prevent the state from authoritarianism but also to avoid chaos, violence, and brutalism by the crowds in the name democracy or participation.

People give their participation in two ways: first is to participate as voters in public elections (representative democracy); and

1 The instance of it is the Monas incident on June 1, 2008, between Moslem Defender Front (Front Pembela Islam/FPI) and the National Alliance for Religious and Belief Freedom (Aliansi Kebangsaan untuk Kebebasan Beragama dan Berkeyakinan/AKKBB). 
second is to involve more directly in all stages of policy making processes or in public service mechanism (deliberative democracy). In this context, the democracy we promote to shape local development is not only representative but also deliberative one. To make local government accountable to its people, the existence of the later is a necessity.

\section{Social Accountability in Local Development}

Accountability is a fundamental principle of democracy and crucial to make local development meets the will of the citizens. In a democratic country, citizens have the right to demand accountability and public actors have an obligation to account. "Those calling for an account are asserting rights of superior authority over those who are accountable" (Ackerman, 2005: 12). Accountability is the obligation of power holders to account for or take responsibility for their actions. Power holders refer to those who hold political, financial or other forms of power and include officials in governments, private corporations, international financial institutions and civil society organizations (Malena, et.al., 2004: 2).

To develop more accountable local governance, citizens' participation is the key point. Citizens are the target of local governance improvement efforts. They need to be empowered to make them more aware of their rights as citizens and to make them more capable to voice their interests, to complain the service providers when they receive unfair treatments or when they see certain government wrongdoings, or to propose particular development programs. But at the same time, the citizens as individuals or as parts of citizen organizations or nongovernment organizations can play strategic roles to push the government to reform their regulations, planning, budgeting and public service mechanisms to meet the citizens' demand.
Social accountability is an approach towards building accountability that relies on civic engagement, i.e., in which it is ordinary citizens and/or civil society organizations that participate directly or indirectly in exacting accountability. The indirect mechanism of social accountability in democratic states is elections. This indirect participation is a very blunt instrument with which to hold accountable. Even if citizens were fully and accurately informed of the views and actions of every political candidate (which of course far from the case), elections still only allow citizens to select among a limited number of individuals or political parties. They do not offer citizens to express their preferences on specific issues, to contribute in a meaningful way to public decision making or to hold public actors accountable for specific decisions or behaviors.

To gain better social accountability, citizens should be able to participate more directly in policy making process as well as in service delivery mechanisms. There is a broad range of actions and mechanisms (beyond voting) that citizens, communities, civil society organizations (CSOs) and independent media can use to hold public officials and servants accountable. Traditionally, these have included a variety of citizen or civil societyled actions such as public demonstrations, protests, advocacy campaigns, investigative journalism and public interest lawsuits. Such traditional social accountability is often seen to be closer to the punishment than to the reward side of spectrum; tends to associate social mobilization with anger and protest.

In more recent years, the expanded use of participatory data collection and analysis tools combined with (in many country contexts) enhanced space and opportunity for citizen/ civil society engagement with the state, had led to a new generation of social accountability practices that emphasize a solid evidence base and direct interaction with government counterparts. These include, for example, participatory budgeting, public expenditure 
tracking, citizen monitoring and evaluation of public service delivery. They also include efforts to enhance citizen knowledge and use of conventional mechanisms of accountability (Malena, et.al., 2004: 13). Such new type of social accountability grounded in constructive partnership between civil society and the state. Citizens are mobilizing, often locally, to demand better services, not by shouting, but by counting, making sure that their government spend effectively, and keep their promises. Shouting is often effective. Indeed, it is the only resource civil services are left with. Nevertheless, setting up arrangement of "state-society synergy" which lead to rewards for both side of equation can even be more fruitful (Ackerman, 2005: 13).

Graphic 1 shows how participation shapes local development. First, there must be a favorable climate at international, national, as well as local levels that works as an enabling factor of participatory local development. In this instance, Indonesia have built global partnership with other nations, received aids and advocacy from many international donor agencies, has ratified the United Nations' Declaration on the Right to Development Millennium Development Goals, and enacted laws which provide a legal basis for carrying out participatory local development efforts.

Second, to make local development more participatory, there must be efforts to improve social accountability from supply as well as demand side simultaneously. From the demand side citizens must be empowered, particularly the poor as to make them acknowledge their right as citizens to participate in local development efforts, to

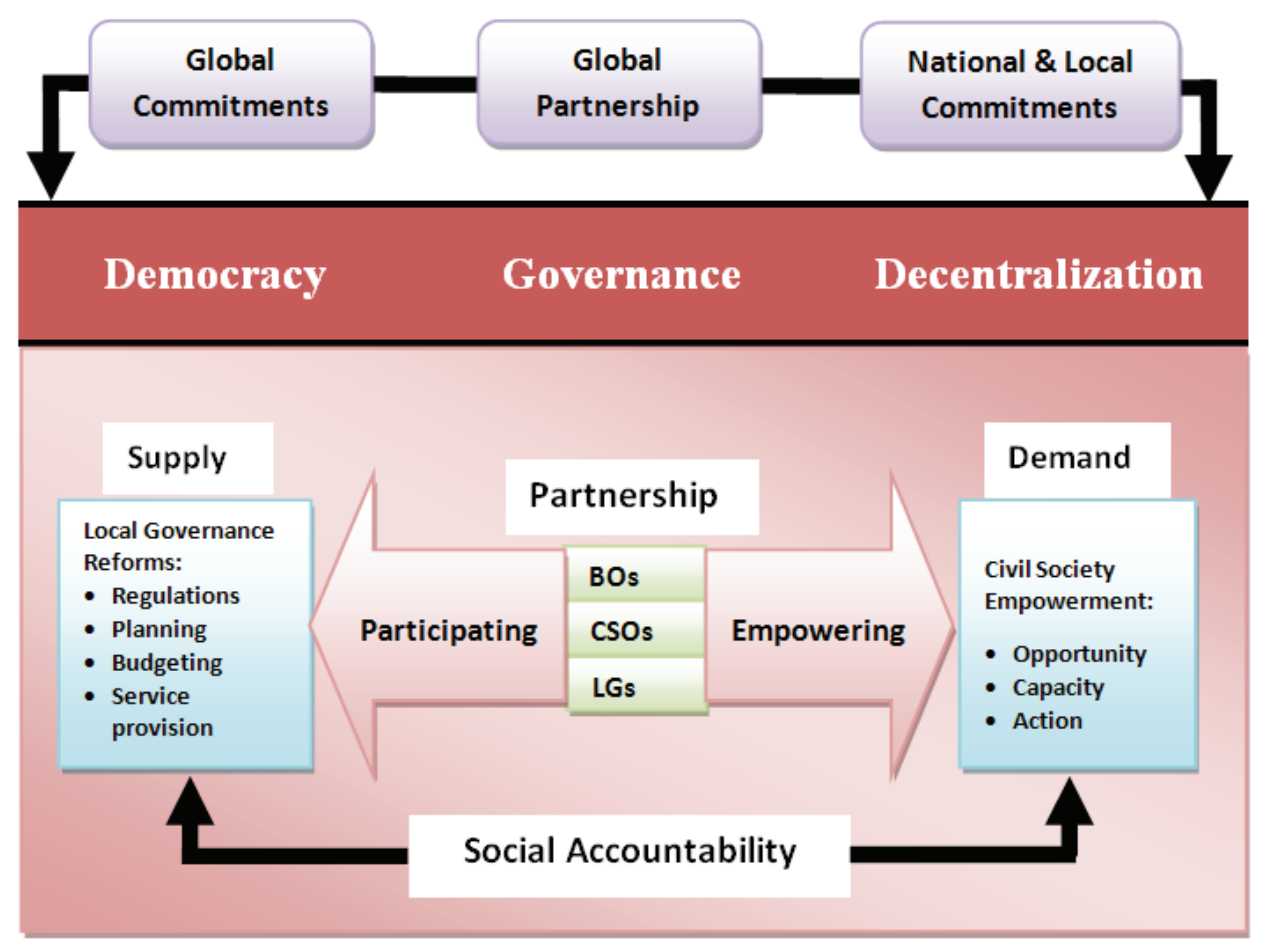

Source: Primary data

Notes:

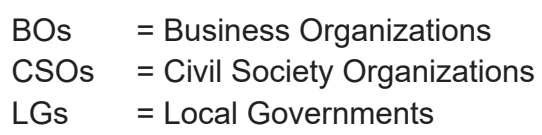

Graphic 1 Two Sides of Participatory Local Development towards Accountable Local Governance 
increase their capacity to participate, and to use the opportunity they have to give full participation in the local development processes. In the meantime, from the supply side is to reform local governance through the enactment regulations, which promote government transparency and the enhancement participatory policymaking, planning and budgeting, and service provision mechanisms. These two side efforts require partnership among local governance stakeholders that includes local governments, business organizations (private sectors) and civil society organizations (mass media, universities, NGOs or citizen organizations). This partnership are built either to empower civil society or to participate in local governance reforms.

\section{The Supply Side: \\ Local Governance Reforms}

Local governance is the way decisions are made and implemented by and on behalf of people in a local area. It includes the allocation of authority to decision makers; the authorization to use collective financial and natural resources, provision of public goods and services, and holding accountable those to whom authority is entrusted. In addition to local governments and other local public sector agencies, local government encompasses a variety of civil society institutions, including resource users groups and citizen oversight bodies linked to public service delivery networks. Local governance institutions also include community development committees, indigenous institutions and traditional authorities, voluntary associations, and nongovernmental self-help organizations (Helling, et.al., 2005: 6).

The three elements of local governancelocal government, business sector and civil society-plays important roles in local development efforts. Indeed, local government remains central in these efforts due to the public mandate it gets from citizens. Business sector is also significant factor of local development. Enabling local private sector growth contributes to the economic basis for local development, both in urban settings where industry and services provide the economic base and in rural areas where agriculture and agribusiness provide economic base (Helling, et.al., 2005: 6). Moreover, business sector though its primary motive is profit, it also assumes to have social responsibilities. Private businesses take a part in public service provision so that clients have more alternatives to choose. Many big corporations deliver social responsibility programs which to a certain degree favor poor or marginalized people.

The enhancement of citizens' participation requires local governance mechanisms reforms toward more transparent, inclusiveand participatory. We can list a number of efforts to make such reforms. LGSP (Local Governance Support Program), which is supported by USAID, builds collaboration among the central government, local governments and civil society organizations to improve participatory, effective and accountable governance in a number of selected provinces in Indonesia. The program that was started in 2005 worked in 60 districts and municipalities to provide technical advocacy and training to improve the capacity of local governments, citizen organizations and media. The advocacy was provided on integrated planning and budgeting, management of local government, public service provision and participatory governance through local council and civil society.

World Bank promote three comprehensive programs: ILGR (Initiative Local Governance Reform), USDRP (Urban Sector Development Reform Project) and SPADA (Support for Poor and Disadvantaged Areas). ILGR is a program that attempts to enhance the transparency, accountability and public participation in the process of decision making to make development more concerned on poverty 
reduction efforts. UNDRP is the program to assist governments in implementing the Urban Institutional development Program (UIDP) and in the formulation of the national policy on urban development, particularly on urban development finance, poverty alleviation through the development of local economy and the improvement of public service provision.

USDRP is a program to assist central government and local government to improve the quality of governance. In the central level, the program helps the government in implementing project management. While in the regency level, it helps district and municipality government to carryout reformation of basic governance, to formulate capacity building and institutional development strategies.

In the meantime, SPADA help the Indonesian government to address problems of governance and poverty in the 100 poorest districts of the country. It draws on the new government's commitment to poverty reduction and to the priority assigned to promoting development in the poor districts now entering post-conflict reconstruction.

\section{The Role of NGOs}

In regards to participation and people empowerment, the role of civil society organizations, particularly the nongovernment self-help organizations (NGOs) needs to get special attention. NGOs' role is unique in shaping local development. First, NGOs grow from within the society so that their existence may indicate the life of civil society. Second, NGOs are partners of governments to improve the demand side of accountability. In this case, NGOs may work independently or collaboratively with the governments to empower citizens through training, advocacy or public actions. They advocate local residents to do participatory rural assessment, participatory local or village planning, participatory local or village budgeting, and self help community programs on housing, small enterprises, health, environment, etc. Third, NGOs can work from the reverse that is to improve the supply side of accountability. In this instance, NGOs may collaborate with citizens' organization or residents to push the local government to do certain governance reforms (to construct new regulations, to develop new mechanisms of policy making or public service provision), or to control governments' programs and public service provisions.

CSOs are apparently not new institutions in the history of Indonesian politics. Even during the era of Dutch occupation we have already had them (Muhammadiyah, NU, Tamansiswa, etc.), also during the Soekarno's or Soeharto's eras we have already had a number of NGOs which work in various public issues, such as family planning, gender, poverty, or environment. But the rate of growth in the last 10 years is amazing. Nowadays the number of CSOs all over the country is around 2,000 (see Graphic 2) but spread unequally among regions. The rapid growth of NGOs may be due to euphoria of democracy after the fall of Soeharto's power but probably also because of the international pressure. Most international aids require the recipient governments to collaborate with NGOs in conducting public programs.

SMERU's figure that was collected in 2004 is much higher compared to LP3ES data that was collected three years earlier (2001). The reason of this big difference may be because of time difference in data collection but it could be also because they define CSOs differently. SMERU's definition is wider that includes all non-state organizations, such as religious based student organizations. This graphic shows that CSOs in Indonesia is quite large in number, at least if we compare with the previous decades. The booming momentum happened from the 1980s to the 1998 reformation period. 


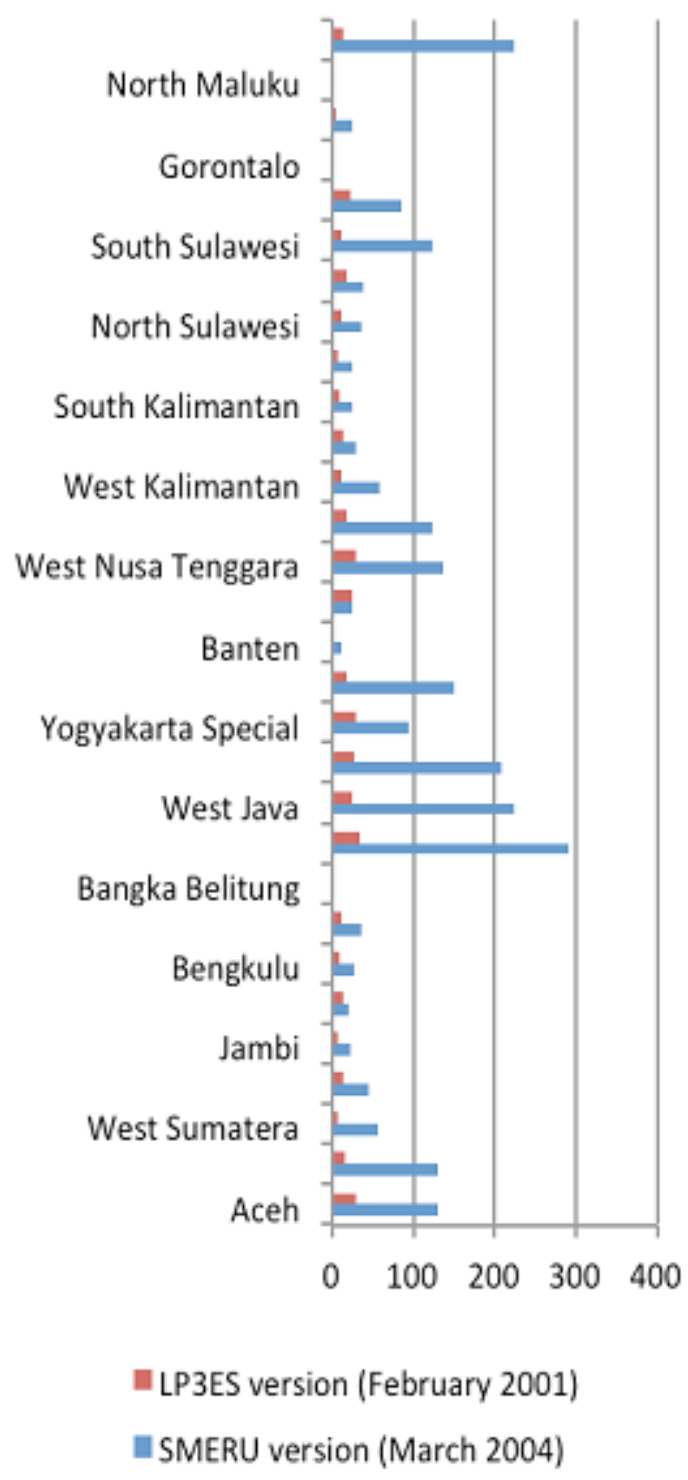

Source: drawn from Table 1, S2-PLOD (2008: 13)

Grapic 2 CSO Densities in Indonesia per Province

The analysis made by PLOD UGM indicates an orientation shift of CSOs toward government reform related issues. During the Orde Baru era, the main issues were human rights, democracy and development. Nowadays, CSOs concern on more specific government reform issues, such as policy advocacy for governance reform, which includes rural development or reformation of regency governments. In West Java, for instance, Bandung Institute of Governance Studies (BIGS) Akatiga Foundation was established. Indonesian Partnership on Local Governance Initiative (IPGI) was established in Surakarta, Bandung and Dumai Municipalities while Parwi Foundation emerged in Yogyakarta (S2-PLOD, 2008: 13).

\section{The Demand Side:}

\section{Empowerment of Local Citizens}

Empowerment is the starting point for local development. Empowerment is the process of enhancing the real possibility that an individual or a group can make and express choices, and transform their choices into desired actions and outcome. Individuals, households, and communities need both opportunity (the availability of options for meaningful decisions and actions) and capability (the ability to make meaningful choices and act on them and express them through institutions open to popular "voice") in order to be truly empowered (Helling, et.al., 2005: 6).

The outcome of citizen empowerment efforts is citizen engagement: a citizenry actively engaged in civic life-taking responsibility for building communities, solving community problems and participating in the electoral and political process. Civic engagement is an individual and collective actions designed to identify and address issues of public concern. The engagement is not only shown on citizens' actions and efforts but also on a feeling of belonging, an experience of investment and ownership in the local, regional, national, and/ or international political communities to which citizens belong. It works to make a difference in the civic life of our communities and developing the combination of knowledge, skills, values and motivation to make that difference (MOCS Website and Wikipedia). 


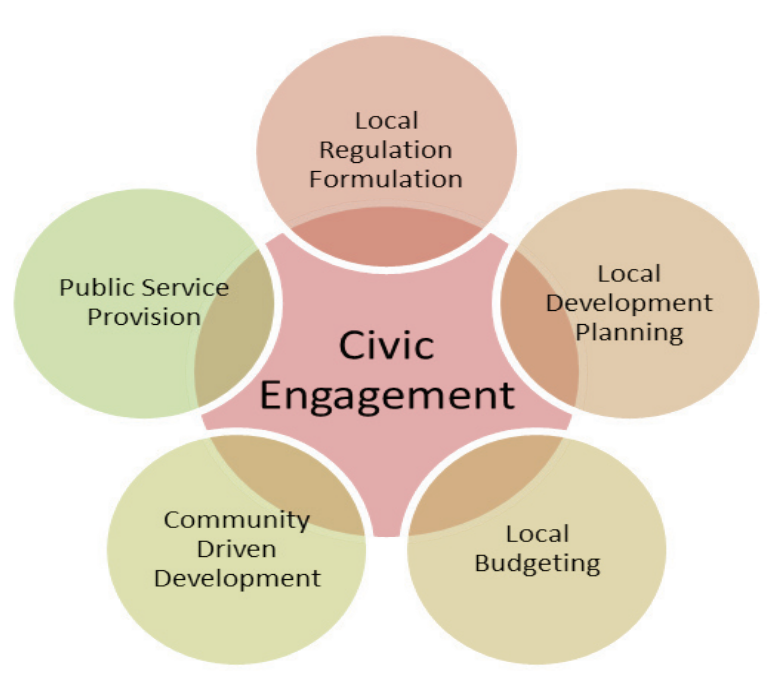

Source: Primary data

Graphic 3 Civic engagement in Five Forms of Local Development Efforts

After the ratification of Law No.22/1999, a lot of efforts have been made to reform local governance to give citizens more access to participate. In many local areas, people are empowered as to make them acknowledge their own rights as citizens and have capacity to voice and involve in local development processes. Having opportunity and capacity to voice and make a choice, civil society is engaged at least five forms of local development processes (see Graphic 3).

The first form is in the formulation, implementation and monitoring of local regulation to build local governance transparency. In this instance, NGOs and residents (warga) act as a team to influence local regulation (perda) or to propose an alternative draft of local regulation. They may also work in partnership to express their objection toward a certain local regulation or to report violence against a certain local regulation or violence against a higher-level regulation.

The second form of development process, which demands for citizens' participation is local development planning mechanism.
Citizen organizations together with local government bodies and NGOs discuss programs or projects, which will be funded by the local government in the coming budget year. They may give a response to a planning document published in a media, to involve in a public debate on a planning draft prior to ratification, or to monitor and evaluate local development implementation.

The third kind of local development processes is budgeting. Citizens' delegates may involve in budget formulation process in musrenbang or public consultation. They may present their budget version as an alternative on the budget formulation process in a local council. After the budget document has been endorsed, they may work in partnership with other stakeholders to do analysis on the budget allocation and its impact on people.

The fourth citizens' participation is on community driven development (CDD) programs. CDD is an approach that transfers control over resources and decision making to local communities. CDD programs provide grants for scale investments that are chosen, designed and implemented by communities. The investments could be for the development of basic infrastructures such as water supply and road, social services including health and education intervention and productive investments in areas like small-scale irrigation, agricultural production or development of informal sector activities. In such programs, partnership is developed among stakeholders who include CBOs, local governments, NGOs and private firms.

The fifth form of local development in which people are able to participate is public service provision. Citizens' organization may negotiate with service providers to develop standards of access, coverage and quality of services through citizen charter; or they may monitor access, quality and people satisfaction to public services through Citizen Report Card. 
Table 1 Forms of Participation on Number of Coverage Issues

\begin{tabular}{|c|c|c|c|}
\hline $\begin{array}{l}\text { Coverage of } \\
\text { Issues }\end{array}$ & $\begin{array}{l}\text { Form of } \\
\text { Participation }\end{array}$ & Character & Cases \\
\hline \multirow[t]{4}{*}{$\begin{array}{l}\text { Local } \\
\text { Regulation }\end{array}$} & $\begin{array}{l}\text { Citizen proposal/ } \\
\text { alternative draft }\end{array}$ & $\begin{array}{l}\text { NGO and residents (warga) } \\
\text { work together to mobilize } \\
\text { themselves to influence } \\
\text { local regulation (perda) }\end{array}$ & $\begin{array}{l}\text { Jeneponto, Jatim, } \\
\text { Alor, Palu }\end{array}$ \\
\hline & $\begin{array}{l}\text { Public consultation, } \\
\text { constituent } \\
\text { meeting, Public } \\
\text { Hearing (Rapat } \\
\text { Dengar Pendapat } \\
\text { Umum) }\end{array}$ & $\begin{array}{l}\text { Government, NGOs, Citizen } \\
\text { Organization (organisasi } \\
\text { warga) communicate to } \\
\text { discuss local regulation. }\end{array}$ & $\begin{array}{l}\text { Alor Lebak, Jepara, } \\
\text { Palu, Madiun, Kediri, } \\
\text { Mojokerto }\end{array}$ \\
\hline & $\begin{array}{l}\text { Objection to a } \\
\text { Local Regulation }\end{array}$ & $\begin{array}{l}\text { NGOs and citizen } \\
\text { organization work together } \\
\text { and mobilize them to } \\
\text { express their objection } \\
\text { toward a certain local } \\
\text { regulation. }\end{array}$ & $\begin{array}{l}\text { Syariat local } \\
\text { regulation (Padang, } \\
\text { dll), Manokwari, Perda } \\
\text { Jakarta }\end{array}$ \\
\hline & $\begin{array}{l}\text { Reporting Local } \\
\text { Regulation violation }\end{array}$ & $\begin{array}{l}\text { NGOs and Citizen } \\
\text { Organizations work together } \\
\text { to report violence against } \\
\text { a certain local regulation or } \\
\text { violence against a higher } \\
\text { level regulation. }\end{array}$ & $\begin{array}{l}\text { Bandung Municipality } \\
\text { (Zoning), the Local } \\
\text { Regulation on Zakat } \\
\text { Obligation for Public } \\
\text { Officials }\end{array}$ \\
\hline \multirow[t]{4}{*}{ Planning } & $\begin{array}{l}\text { Development } \\
\text { Planning } \\
\text { Discussion } \\
\text { (musrenbang) }\end{array}$ & $\begin{array}{l}\text { Government, NGOs and } \\
\text { Citizen Organization discuss } \\
\text { programs and projects } \\
\text { which will be funded by the } \\
\text { government in the coming } \\
\text { budget year. }\end{array}$ & $\begin{array}{l}\text { Almost in all districts } \\
\text { and municipalities in } \\
\text { Indonesia }\end{array}$ \\
\hline & $\begin{array}{l}\text { Information through } \\
\text { mass media }\end{array}$ & $\begin{array}{l}\text { Government, NGOs, and } \\
\text { the Press work together } \\
\text { to publish a planning } \\
\text { document in mass media }\end{array}$ & $\begin{array}{l}\text { Bandung } \\
\text { Municipalities }\end{array}$ \\
\hline & $\begin{array}{l}\text { Public Debate } \\
\text { (workshop) }\end{array}$ & $\begin{array}{l}\text { Government, NGOs, and } \\
\text { Citizen Organization Work } \\
\text { together to discuss a } \\
\text { planning draft-space and } \\
\text { program-which will be } \\
\text { ratified by the government. }\end{array}$ & $\begin{array}{l}\text { Almost in all districts } \\
\text { and municipalities }\end{array}$ \\
\hline & $\begin{array}{l}\text { Monitoring and } \\
\text { evaluation of } \\
\text { development } \\
\text { implementation }\end{array}$ & $\begin{array}{l}\text { NGOs and citizen } \\
\text { organization work together } \\
\text { to mobilize themselves to } \\
\text { monitor the implementation } \\
\text { of a certain development } \\
\text { program }\end{array}$ & Lebak, Sumedang \\
\hline Budgeting & $\begin{array}{l}\text { The involvement } \\
\text { of musrenbang } \\
\text { delegation on KUA, } \\
\text { PPAS, RKA, }\end{array}$ & $\begin{array}{l}\text { Citizen delegation involve } \\
\text { in a budget formulation } \\
\text { process }\end{array}$ & Sumedang, Lebak \\
\hline
\end{tabular}


Public Consultation Governments, NGOs, and Citizen Organization communicate to discuss policy planning and budget draft

Analysis and presentation of a budget alternative

Publication and analysis of Budget Order Draft (DPA: Dokumen Perintah Anggaran)

NGOs and Citizen

Organizations do analysis works and present their budget version as an alternative on the budget formulation process in a local council

Government, NGOs, and the budget document that has been endorsedeither in the form of poster Citizen Organization publish or mass media-and do analysis on the budget allocation and its impacts on people

\begin{tabular}{ll}
\hline Public & Citizen' Charter \\
Service &
\end{tabular}

Citizen Report
Card

Complaint

Mechanism
NGOs and Citizen Organization monitor access, quality and people satisfaction to public services

Governments develop mechanism to patch citizen complaints toward public services and to mediate conflicts between citizens and public service providers
Bandung and

Sumedang Districts

Bandung District

Bandung District

\section{Bima District and a number of districts and municipalities} facilitated by the Center for Population and Policy Studies, Universitas Gadjah Mada (Yogyakarta Municipality, Semarang District and, Blitar Municipality)

Lebak, Magelang and Ngawi Districts, Bandung and Semarang Municipalities, East java, etc.)

Semarang

Source: Suhirman, 2005: 3 


\section{Civic Engagement in Local Regulation Processes}

Elements of local governance collaborate to strengthen civil engagement through two main strategies. The first strategy is the establishment of citizen forums. In Blitar Municipality, they form the Stakeholders Teamwork (TKS); in Bangkalan Stakeholders Communication Forum (FOKUS); in Kediri Municipality Communication Forum for Urban Development (FKPP); in Surabaya City Council; and in Majalaya (Bandung) Majalaya Society Forum for Welfare (FMMS). These forums facilitate the citizen involvement on local public policy processes and at the same time pool the citizen energy into a solid network for joint actions. In this instance, the NGOs' instinct to put local government as their "common enemy" seems remain strong.

The second strategy is to advocate governments in the process of local government formulation in order to have participatory local regulations. In this instance, they propose the institutionalization of citizen participation space on local policy processes, so that the citizen participation has legal basis. This second strategy does not put the NGOs and citizens to stand opposite to the government, instead they call for collaboration and partnership. As a result, a number of districts and municipalities have passed participatory local regulations.
Takalar District enacted Local Regulation No. 13/ 2002 on the Supporting System (SISDUK) and the Regent Circular Letter no. 415.4/453/ BAPPEDA/2001. This regulation encourages societies to plan and execute their own program with budget sharing between government-using local government budget-and societies/NGOs. In Probolinggo Municipality, Local Regulation No. 5/2003 regulates citizen participation on development planning through the establishment Participatory Planning Forum Communication Forum for Development Dialogue and by providing participatory budget stimulus. Similarly, in Kupang District through Local Regulation No. 18/2000 on Mechanism Pattern for the Empowerment of Local Societies. Solok Municipality has Local Regulation No. 5/2004 on the Transparency of Government Execution. This regulation regulates clearly and operationally public information access mechanism. A comparable regulation that guarantees citizens' access to get information is in Gorontalo Municipality (Local Regulation No. 3/2002) which gives sanction to public officials who consciously hide information of the local government activities. Another instance of participation institutionalization is in East Java where the province government enacted local regulation on public services in which the process involves CSOs, academicians, and citizen organizations (S2-PLOD, 2008: 16). 
Table 2 List of Regencies and Municipalities which have Regulation on Clean Government Execution Transparency (Transparansi Penyelenggaran Pemerintahan yang Bersih)

\begin{tabular}{|c|c|}
\hline $\begin{array}{l}\text { Name of Regencyl } \\
\text { Municipality }\end{array}$ & Local Regulation/Circular Letter/Decision Letter \\
\hline Takalar Regency & $\begin{array}{l}\text { Local Regulation No. } 13 / 2002 \text { on Supporting System } \\
\text { (SISDUK). } \\
\text { This regulation encourages people to plan and carry out their } \\
\text { own program, the cost is shared with the local government } \\
\text { using APBD, society and CSO } \\
\text { The Regent Circular Letter No. } 415.4 / 453 / B A P P E D A / 2001 \\
\text { on Local Government Support to the involvement of the third } \\
\text { sector or societal groups on the formulation and implementation } \\
\text { of government programs }\end{array}$ \\
\hline Solok Regency & $\begin{array}{l}\text { Local Regulation No. } 5 / 2004 \text { on The Transparency of } \\
\text { Government Execution and Community Participation } \\
\text { (Transparansi Penyelenggaraan } \\
\text { Pemerintahan dan Partisipasi Masyarakat). This regulation } \\
\text { regulate clearly and operationally the public information access } \\
\text { mechanism. }\end{array}$ \\
\hline Gorontalo Municipality & Local Government No. 3/2002 on Information Freedom \\
\hline Probolinggo Municipality & Local Regulation No. 5/2003 on Participation \\
\hline Kupang Regency & $\begin{array}{l}\text { Local Regulation No. } 18 / 2000 \text { on the Local Community } \\
\text { Empowerment Mechanism Pattern (Pola Mekanisme } \\
\text { Pemberdayaan Masyarakat Daerah) }\end{array}$ \\
\hline Sidoarjo Regency & $\begin{array}{l}\text { Regent Decision Letter No. } 68 \text { on the establishment of Medical } \\
\text { Committee for Local General Hospitals (RSUD) with the } \\
\text { community membership element. The purpose is to control the } \\
\text { quality of health services }\end{array}$ \\
\hline Gowa Regency & $\begin{array}{l}\text { Local Regulation No. 04/2004 on the People Participation in the } \\
\text { execution of Gowa Regency Government. } \\
\text { Local Regulation No. } 22 / 2003 \text { on General Urban Regional } \\
\text { Planning Tombolo Municipality. Tombolopao Sub-district 2003- } \\
2013\end{array}$ \\
\hline $\begin{array}{l}\text { Bandar Lampung } \\
\text { Municipality }\end{array}$ & $\begin{array}{l}\text { Local Regulation No. } 13 / 2002 \text { on People Participation in the } \\
\text { formulation of Local Income and Expenditure Budget (APBD) }\end{array}$ \\
\hline East Lampung Regency & $\begin{array}{l}\text { Local Regulation No. 5/2003 on Community Based } \\
\text { Development Planning (P2BM) }\end{array}$ \\
\hline West Lampung Regency & $\begin{array}{l}\text { Local Regulation No. } 18 / 2004 \text { on Community Based Natural } \\
\text { and Environment Utilization }\end{array}$ \\
\hline Lebak Regency, Banten & $\begin{array}{l}\text { Local Regulation No. } 6 \text { Th. } 2004 \text { on Transparency and } \\
\text { Participation in Government Execution and Development } \\
\text { Management (Transparansi dan Partisipasi dalam } \\
\text { Penyelenggaraan Pemerintah dan Pengelolaan Pembangunan) } \\
\text { in Lebak District }\end{array}$ \\
\hline $\begin{array}{l}\text { Wonosobo District, } \\
\text { Central Java }\end{array}$ & $\begin{array}{l}\text { Local Regulation No. 22/2001 on Commmunity Based Forestry } \\
\text { Resource Management (Pengelolaan Sumber Daya Hutan } \\
\text { Berbasis Masyarakat) (PSDHBM) }\end{array}$ \\
\hline
\end{tabular}

Source: S2-PLOD, 2008 


\section{Participatory Planning}

Discourses on a participatory development planning discourse has apparently begun since 1990s, a few years before the reformation. However the state has successfully enacted laws that are corresponding to these ideals throughout this decade. Participatory planning and budgeting has got legal recognition in the Law no.22/1999. The law adopts decentralist planning approach. Local governments have a wide authority and get proportional fund (dana perimbangan) so they should also have an authority to formulate local planning even though not absolute for the local planning should be compliant with central government planning. In the meantime, Law No. 17/2004 on Public Finance, Law No. 25/2004 on National Development Planning, Law No. 32/2004 on Local Government, and Law No. 33/2004 on Finance Balance between Central and Local Governments regulate national as well as local annual planning and budgeting. As a technical guidance to local planning, Department of Home Affairs and National Development Planning Board (Bappenas) update Joint Circular Letter annually on musrenbangda (Local Development Planning Dialogue).

Based on Law No. 25/2004 and Law No. $32 / 2004$, the formulation of Local Government Work Plan (RKPD) starts with Bappeda's activities which originate the first draft of RKPD. Then the heads of Local Apparatus Working Unit (SKPD) prepare RKPD work plan (renja) in accordance with their main tasks and functions and refer to the original draft of RKPD and based on the SKPD's strategic Plan (renstra-SKPD). After the Renja SKPD created, the head of Bappeda coordinates the construction of the RKPD draft using Renja SKPD. The RKPD draft is prepared by Bappeda used as an input on the Development Planning Dialogue (musrenbang) to formulate RKPD which includes elements of societies and government bodies. The musrenbang to formulate RKPD is organized by Bappeda no later than March. Based on musrenbang outcome, the head of Bappeda formulates the last draft of RKPD. The RKPD is ratified as the Regulation of District/Municipality Head and to be a guidance of the Local Development Revenue and Expenditure Planning (RAPBD) formulation.

In this scheme, the development planning system exercises four types of processes. The first is a political process. The Local Middle Term Development Planning (RPJMD) is reduction of the vision and mission of the elected district/municipality head. Another political process is the requirement of communication and dialogue between the executive (lead by the district/municipality head) and the legislature (local council or DPRD). The second is a technocratic process. Professional planners or the government institutions that have a functional role on planning prepare the planning. In accordance with Law No. 28/2005, Bappeda and SKPD do the technocratic process. The third is participatory process. Planning involve societies or citizens through musrenbang started at the village level. The forth is a mix of top-down and bottom-up processes. Top-down means that the local plan should be in accordance with the national plan and correspondingly the regents or municipals should conform to the president. Meanwhile, the bottom-up process is the process of formulating annual plan which start with musrenbang at a village level, goes up to subdistrict, regency/municipality, province, and central levels.

Musrenbang, in 1980s called rakorbang (the Development Coordination Meeting), is a forum to implement bottom-up up or participatory model of local development planning. The process begins at countryside (dusun) level called musrenbangdus. Its output is brought to a village level into musrenbangda then goes up to a subdistrict level called the Inter-Village Dialogue (musyawarah antardesa), previously called UDKP. It finally goes to musrenbangda. The process of aggregation happens in the form of 


\section{Box 3}

Margono, the Village Head of Burat, Kepil Sub-District:

"We start development planning from empowerment; we start the empowerment by giving the poor citizens to speak and tell the problems they face. My job is just to facilitate their aspiration. Due to the empowerment, they become more critical and recognize the problem and the potential they have."

Source: Eko, 2008:15

selecting the priorities among all inputs from the lower level dialogue. The village, through the LPMD (previously LKMD) forum, selects proposals from the countryside; similarly the dialogue at sub-district level decide the priority by selecting proposals come from the village level, so does in the district level. At least officially, this participatory process includes all relevant stakeholders (Eko, 2008: 20).

Eko's study notes that some musrenbang process in the village and sub-district level has followed consistently the Joint Circular Letter on Participatory Development Planning Dialogue (ESB Musrenbang). The dialogues have involved all elements of societies, including women. Yet the documents have failed to insert in-depth poverty vulnerability map, and tend to prose more on physical infrastructure. The dialogues in sub-district level have already been attended by all relevant stakeholders, including villages' delegates; Bappeda team, SKPD and DPRD, but the time used more for delivering speech instead of discussing in-depth the village delegate proposals (Eko, 2008: 14).

The question is how good the musrenbang works? Eko (2008: 15) reported in his study that most districts have practiced participatory planning and pro-poor budgeting. All districts have had a document of the Middle Term Local Plan (RPJMD) and Local Poverty Reduction Strategy (SPKD) which guide the formulation of an annual planning. This document refers to the national plan and involves all elements of the society. In collaboration with NGOs,
Wonosobo District has already had SKPD which was drafted based on the Participatory Poverty Assessment (PPA) in all villages. Even the RPJMD paper the development priority in Wonosobo has been focused on poverty alleviation through the provision of the basic needs services, small economy (ekonomi rakyat), empowerment and infrastructures (roads and electricity), the process started earlier to focus its policy on poverty alleviation through the rehabilitation of basic services (housing, poor families, health insurance, and pro-poor growth).

A micro data from villages in Kepil SubDistrict, Wonosobo shows a growing progress of community empowerment. The village government and its citizens has been more familiar with pro-poor budgeting and gender budgeting and its benefit to the poor in the village (see Box 3).

Eko's study also found that planning process from societies does not determine the final formulation of the local planning. People said, "The bottom up planning process is only in paper, in reality it is "mboten up" (does not go up)". Year after year, people in Purbalingga and Wonosobo Villages have informed their proposal to rehabilitate broken streets but they found no realization. The local government often argues that they have limited amount of budget to meet the people demand. Wonosobo as well as Purbalingga Districts need about Rp11 billons to allocate while in fact the APBD is only Rp1 billion so only 8 percent of this demand they can realize. 
percentage

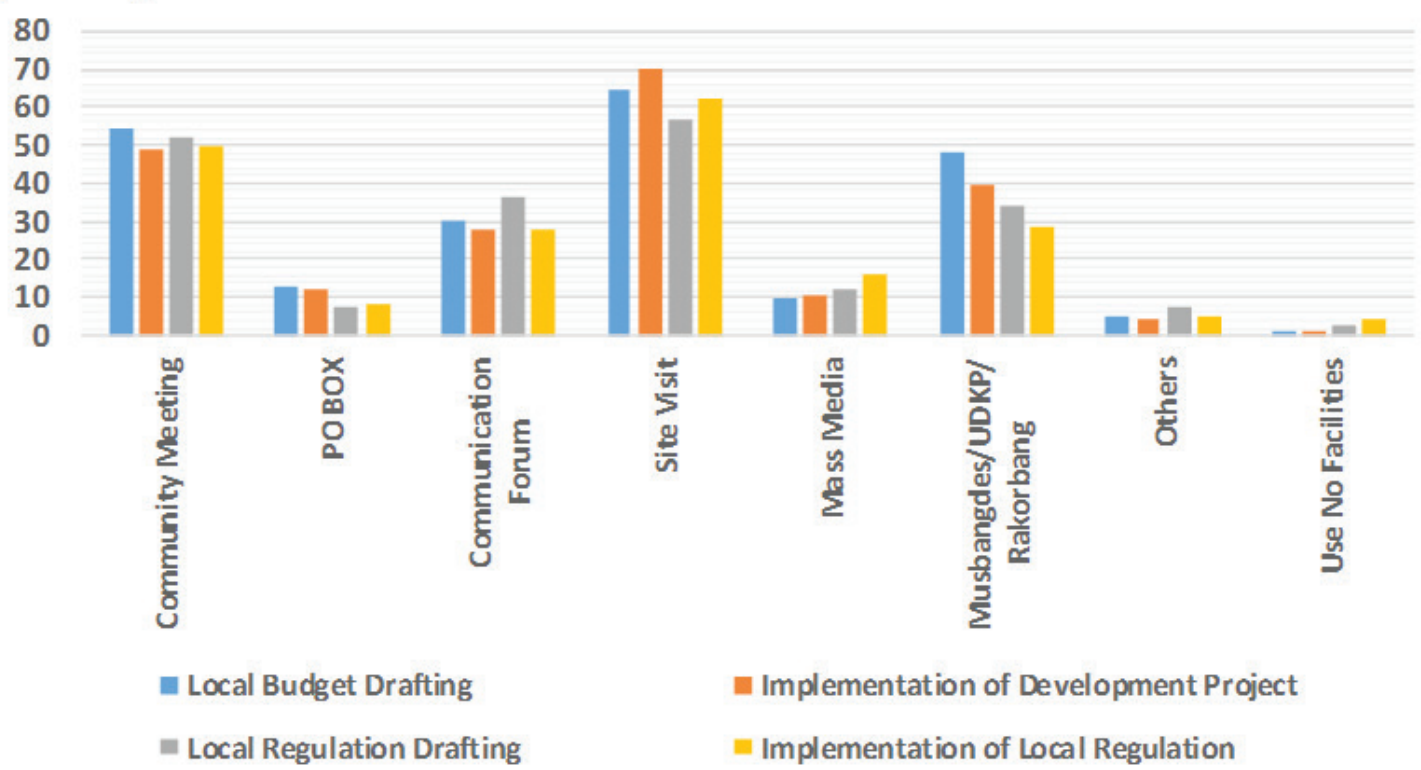

Source: GDS Survey, 2002:20.

Graphic 4 Sources of Informations that the Local Council Members Use to Acquire Information from Citizens

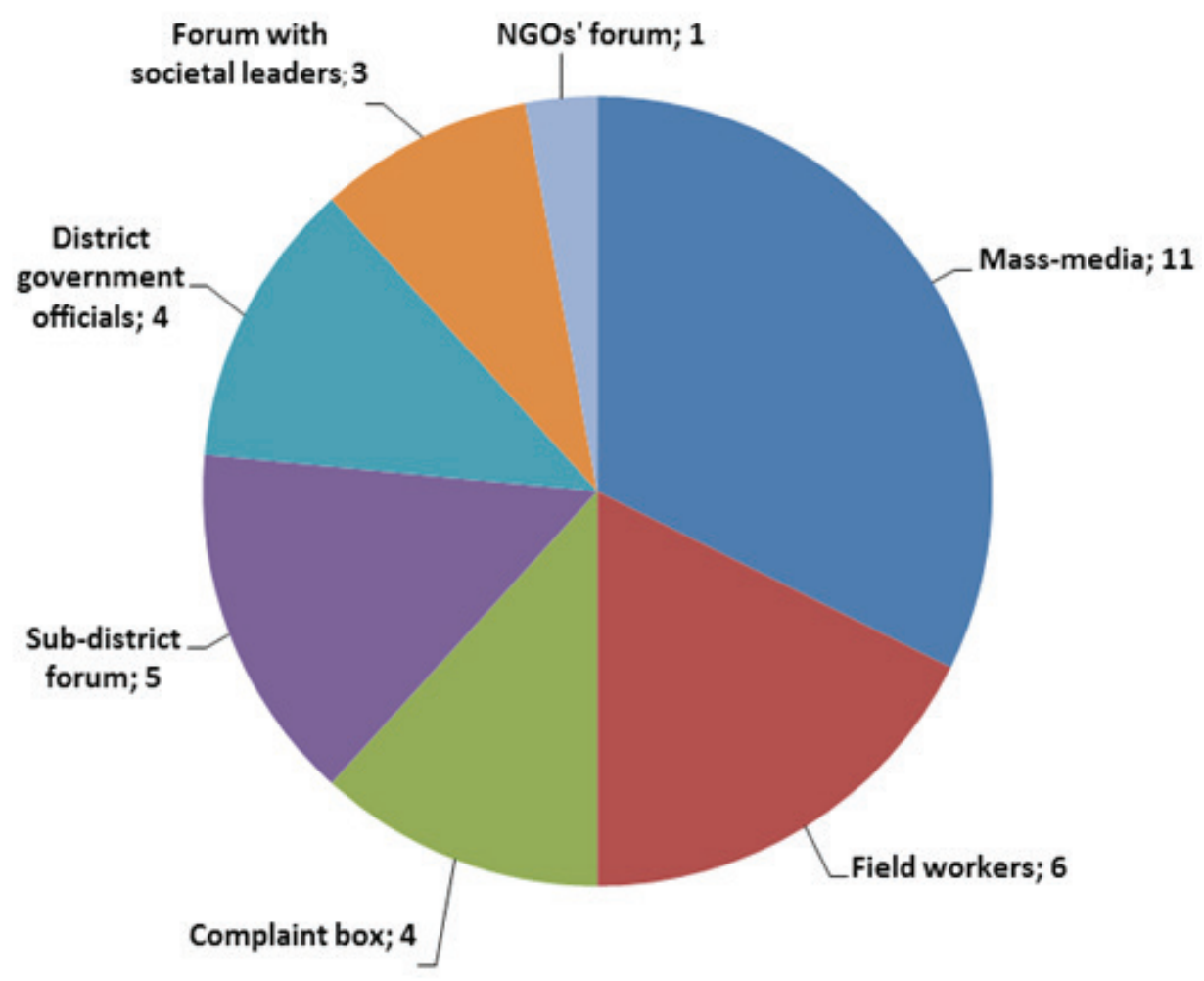

Source: GDS Survey, 2002:20.

Graphic 5 Source of Information the Regents Use to Get People Aspiration 
Data from Governance Decentralization Survey (GDS) $2002^{2}$ shows that the local council members use musrenbang as a facility to acquire aspiration from citizens on many issues, i.e., local budget drafting, implementation of development project, and local regulation drafting, and implementation of local regulation. But musrenbang is not the most important source of information. To gather aspiration from the citizens, they rely more on site visits or community meetings.

The comparable finding is found in GDS2. This survey explores units of organizations that local governments have developed to receive citizens' aspiration by asking regents and mayors as respondents (see Graphic 4). The GDS 2007 findings show that ten out of 13 ILGR districts have had an organization unit which receive such aspiration. Six districts (Solok, Lamongan, Bandung, Kebumen, Magelang, Gowa) put this unit into the Information and Communication Office or other offices. Ngawi and Boalemo Districts put this into a certain complain unit, while the two other districts use other medias such as mass media or complaint SMS. Data from regent respondents also available on types of media and instruments the local governments use to explore people aspirations. As much as 11 regents said that the source of information is mass media; six regents got information directly from field workers and four regents got societal aspirations from complaint and suggestion (see Graphic 5).

\footnotetext{
2 This survey is a World Bank project in which the data is collected by the Center for Population and Policy Studies, Universitas Gadjah Mada. GDS has been done three times up to recently. GDS1 (2002), GDS1+ (2002), and GDS2 (2006). GDS is a survey that measures the impacts of regional autonomy on the quality of public services. The GDS focuses on three major stakeholders: household (as users of public service provision), health and education facilities (as service providers) and bureaucrats (as regulator/ administrator of the public service). This is the most comprehensive survey in Indonesia that measure the impacts of decentralization on the quality of public services in terms of topic coverage, sampling techniques, survey area coverage, and number of sample. For more detail explanation, see Pattinasarani and Surya (2007).
}

\section{Pro-Poor Budgeting and Gender Budgeting}

Budgeting reformation toward pro-poor and gender oriented is closely related to the issues of inequality, gender bias, poverty and backwardness, and parallel to poverty reduction efforts. Poverty is a paradox of Indonesia's development, which is highly concentrated on economic growth. There is s strong empirical evidence that the high economic growth during three decades of The New Era government has positive correlation with the reduction of people living under the poverty line. The poverty number declined from 40.1 percent in 1976 to 11.34 percent in 1996 (before the crisis). But that high growth was apparently a bubble that lies above vulnerable economic foundation. Economic crisis in 1987/8 has made the proportion of poor people went up to 23, 4 percent in 1999. The number then declined into 15.97 percent in 2000 and 15.97 percent in 2005. But the oil price increase that was accompanied by the 33 percent increase of rice price on February 2005 to March 2006 due to the government rice import ban have contributed to increase poverty number from 16 percent in February 2005 to 17.75 percent on March 2006.

Budget is an annual formal government statement on revenue and expenditure estimation. Hence, it is financial planning which represent public policy choices to overcome public problems or to achieve public goals. According to Musgrave (1959), budget has three basic functions, namely allocation (to control directly or indirectly the provision of goods and services in many sectors, i.e. education, health, food, housing, etc.), distribution (to distribute resources and their utilization to reach all segments of the people equally), and stabilization (to stabilize macro economy, keep inflation and unemployment low). These three functions of budget have multidimensional character, not only economic, accounting, administrative, but also political. 
Budget is an economic document, an instrument to balance the distribution of income, to stimulate the economic growth, to enhance job opportunities, or to stabilize macro economy. As an accounting document, budget is guidance or ceiling for government expenditures. Budget is also a managerial or administrative document, an instrument to manage and direct the provision of public services. But, more than that, budget is a political document, allocation of scare resources to people that have complex, competitive and even conflicting interest (Hyde, 1992). For the reason that budget is a political document and contains "citizens' money" there must be a transparency in managing the budget. "If the budget is to become pro-poor (i.e. its expenditure and revenue decisions are more sensitive to the interests of the poor) it is important that the poor themselves participate in its formulation, implementation and monitoring in a manner that is equal, inclusive and collegial" (United Nations, 2005: 14).

While most local governments in Indonesia are committed to improving service delivery, there remains a gap between such statements and the way in which local governments plan, raise, and spend their resources. Budgets are the central tool for planning and managing resources. Integrating a pro-poor, participatory perspective can have profound implications for service delivery and poverty reduction outcomes. The requirement to produce an SPKD provides an opportunity for districts and provinces to ensure that budgets fund investments with poverty-reducing outcomes. It supports the MTDP 2004-2009 call "to mainstream poverty reduction efforts in the national economic agenda." Experiences in Brazil, South Africa, and elsewhere demonstrate that budgets based on increased participation, transparency, and accountability have real development results. Indonesia has begun to introduce participatory planning at various local levels through the musrenbang process, but the meetings focus more on local leaders' priorities than on enabling debate between community members and local governments. It is important to be realistic; when project affordability is not taken into account, the process results in little more than unrealistic, unfunded wish lists. SPKDs should be seen as action plans that are guided by national-level and provincial-level strategies, and budgets are a way to operationalize the plans (ADB, 2005: 2).

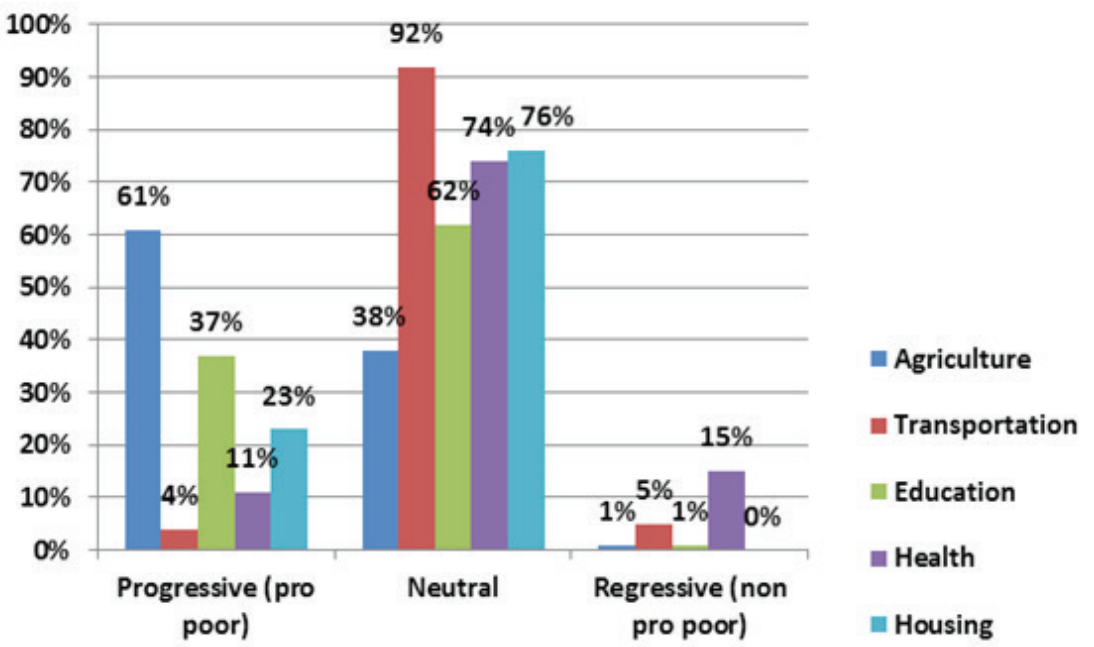

Source: GDS Survey, 2002: 20.

Graphic 6 Budget Policies in Selected Sectors of Local Development 


\section{Muhadjir Darwin}

The implementation of pro-poor budgeting varies among districts and municipalities. Some districts took a lead in innovation. Jembrana District has adopted the new budgeting model since 2001. This innovation was started from Regent I Gde Wisena who wanted to change the old paradigm of "politics as commander" into "management as commander". His innovative ideas to reform the government, including the budgeting system got tough resistance from the bureaucrats and politicians in the local council. While the technocrats were working on budget calculation, he approached politicians, took the leadership of DPC PDIP, and struggled to get political supports from minority groups and the grassroots. It took almost a year to get political supports and after he gained a conducive political climate and held power to make a change, he revitalized the institutions and reformed the budgeting system: rationalized bureaucracy, to cut down the bureaucratic structure, restructured the mechanism of goods provision and control the provision tightly, shaped the budget to be more efficient and reallocated it in order to improve people access on education and health services, and to move the local economy (Eko, 2008: 16). Other districts and municipalities have also made an innovation on budget and public service provisions. To name a few are Sragen, Sinjai, Purbalingga, Bandung, East Belitung, Blitar, Lamongan, Gorontalo, Yogyakarta, and many others. Graphic 6 shows a number of districts and municipalities that have already adopted propoor budgeting.

\section{Box 4 Poverty Reduction and Allocation of DKI Province Budget}

Local Revenue and Expenditure Budget of DKI Province year 2001 earned a lot of criticism because of two reasons. First, the ratification process by the local council was claimed as illegitimate, and second, the expenditure allocation was claimed to prioritize the interests of bureaucrats (also the council members) rather than public interests. The amount of routine expenditures (as representation of expenditures for bureaucrats) reached $67 \%$ while expenditures for development (as representation of expenditures for public services) only $33 \%$.

As a consequence, the coalition of eleven NGOs had sued to the DKI Province Government and the DKI Council. The indications of expenditure inequalities are as follows.

1. Number of poor residents in DKI is 284,709 people, while the budget expenditure allocation that goes directly for the poor interests was only Rp130.5 billion $(5.2 \%$ of development expenditure or 1.7 percent of the total budget. This means that 1 person receive Rp458 thousands a year.

2. The budget allocation for the council member welfare (85 persons) was Rp67 billion a year (for representation, packet, allowance, and official dresses). To add with expenditure allocation for the council secretariat that reached Rp78 billion, so the total budget routine was Rp145.9 billion. The amount of budget allocation to support the interests of 85 persons was higher than for 284.7 thousand people. In other words, "people money" used to support the interest of their "representative" reached Rp1.7 billion per person, or 3,742 times compare to the budget for a poor resident.

3. The routine budget for head of executive (governor and four vice governors), was Rp18.2 billion, or each person used budget Rp3.6 billion.

Based on that data, the question is should the "price" of a "people representative" and "people leader" was that high in comparison to the "price" of the citizens that they represent or lead?

Source: BKBK and SMERU, 2001, Paket Informasi Dasar Penanggulangan Kemiskinan 
How much pro-poor budgeting the local governments have applied? Jasmina, et.al. (2001) analyzes the allocation of local development budget in 268 districts and municipalities, whether it is pro-poor, neutral, or pro-rich. The public expenditure is a) pro-poor (progressive) if the poor get larger proportion of benefits than the rich; b) pro-rich (regressive) if the benefit proportion for the poor is less than the rich gain and $\mathrm{c}$ ) neutral if the proportion of benefit for both is relatively equal. The sample of development sectors are agricultural and forestry, transportation, education, health, and housing and settlement. The results of the analysis are as follows.

1. Among the five sectors, average expenditures for agriculture, education, and housing spent more for the $20 \%$ poorest and 14 percent spent for the $20 \%$ richest while for transportation and health both groups receive almost equal. But, using binary variable, the poor receive benefits less than the rich. In other words, expenditures for transportation and health are between neutral and regressive while on the other three sectors are clearly progressive.

2. The overall analysis by merging the calculation output of sectoral development expenditures with the output of incidence analysis for the five sectors shows that out of 268 districts and municipalities, only 93 percent of them adopted pro-poor budgeting policies. Box 4 provides a case of a budgeting allocation policy performed by DKI Province.

3. Despite quantitative analysis, this study also applies qualitative analysis. The indicators are the existence of a poverty reduction program, participatory budgeting, process and implementation of poverty reduction programs done by the local governments. Out of 40 districts and municipalities, only 18 of them have carried out pro-poor policies.

\section{Civic Engagement in Community Driven Development}

Top-down, centralized and government driven models of community development programs have be the past. To name a few of the past top down, centralist and government driven development programs which result in controversy and people resistance were the dam-building project at Kedung Ombo, coercive methods of national family planning program, and the massive transmigration program.

In the currentera of governance, democracy, and decentralization, community development programs tend to be bottom-up, decentralized and community driven. In this model of development, poor people are prime actors in the development process, not targets of externally designed poverty reduction efforts. Control of decisions and resources rests with community groups, who may often work in partnership with demand-responsive support organizations and service providers, including elected local governments, the private sector, non-governmental organizations (NGOs), and central government agencies (Gillespie, 2004: 12).

Experience had shown that, given clear rules of the game, access to information, and appropriate support, poor man and women can effectively organize to provide goods and services that meet their immediate priorities. Not only the poor communities have greater capacity than generally recognized, they also have the most to gain from making good use of resources targeted at poverty reduction (Gillespie, 2004: 18).

According to the World Bank's Voice of the Poor, based on interview with 60,000 poor people in 60 countries, poor people demand a development process driven by their communities. When the poor were asked to indicate what might make the greatest difference in their lives, they responded (1) organizations of their own so they can negotiate 
with government, traders, and NGOs; (2) direct assistance through community-driven programs so they can shape their own destinies; and (3) local ownership of funds, so they can end corruption. They want NGOs and governments to be accountable to them (Narayan \& Petesch, 2002: 1).

CDD model of development has been applied in many sectors of development, education (education boards and school committees), health (posyandu and desa siaga), micro enterprise and finance (Pengembangan Lembaga Keuangan Mikro (LKM) dan Kelompok Usaha Bersama (KUBE) or Development of Micro Finance Institution and Collective Enterprise Group), settlement (Kampung Improvement Programs and Pembangunan Perubahan Bertumpu pada Kelompok (P2BPK) or Development of Change Based on Group), village development (Kecamatan Development Project), and poverty alleviation (Urban Poverty Alleviation Program).

\section{Box 5 Interview with Chris Banes}

From 1975 until 1977 Chris Banes lived in Jakarta and worked for the Kampung Improvement Program (KIP). The KIP started as an Indonesian initiative in 1969. Five years later, the Bank began to get involved in the KIP through the Jakarta Urban Development Project. Since then, the Bank has financed KIP through 15 integrated projects covering some 200 communities. Chris Banes worked on Urban I and II, before he joined the local consulting team in central Java, implementing Urban-III. Between 1978 and 1982, he was also part of the Bank team that prepared and appraised Urban-IV.

The KIP is one of the world's largest urban programs and ranks among the best urban poverty relief efforts ever. Mr. Banes attributes the success of this program to the fact that the KIP was implemented exclusively by local staff. In particular, Chris Banes stresses the strict planning, engineering, design, construction, and cost standards. In addition to that, since the beginning KIP was designed to be sufficiently low-cost to permit rapid expansion throughout the country in a limited time frame.

Mr. Banes mentions as another contribution to KIP's success Indonesia's well-organized communities. Indonesia has a long history of self-help at the village level which was actively encouraged through the KIP. The improvements motivated the population to invest resources and efforts to further upgrade their housing and infrastructure. According to Chris Banes, never has any other slum upgrading project been as successful as the KIP and improved the quality of life of such a large part of the population. Residents are now better educated, household size has declined, and more residents are employed. KIP also contributed to a healthier environment. Access to piped water and public information on sanitary practices reduced intestinal and water borne diseases, with a particular impact on infant and child mortality.

As Chris Banes points out, these impressive results could be attained only thanks to the existence of two indispensable conditions: (a) political commitment of the government and (b) the creation of strictly organized and multidisciplinary KIP-units. Concerning the first, Chris Banes underlines political commitment to support the KIP has been there right from the beginning, since it started as an Indonesian initiative. Banes mentions the former Governor Ali Sadikin who promoted a multisector approach for the KIP. Sadikin was convinced that his staff had to go out into the kampungs, talk to the people through the existing political structures, and attain basic improvements in a short period of time and at a minimum cost.

The strong political support laid the foundation for the building of local KIP-units to implement the upgrading program. These multidisciplinary agencies with selected staff from the respective local governments and infrastructure sector departments were responsible for detailed planning and implementation of the physical works. The emphasis of this organizational structure was on wide and rapid coverage of the target areas by an integrated package of improvements across the sectors. 
Despite the overall positive output of the KIP, it also raised some criticism. As Chris Banes says, neither the local governments, nor the KIP-units focused enough on maintenance. Since KIP lacked a proper routine maintenance program, soon after the upgrading was accomplished, new problems appeared, such as the disintegration of roads, solid waste filling the drainage channels, and the clogging of drainage ditches which exacerbated more problems.

Banes stresses that maintenance programs and their fundings should be considered as an integral part of a project. According to him, appropriate maintenance is absolutely necessary to guarantee the sustainability of an upgrading project. Ad-hoc maintenance programs, driven and funded by the communities themselves, may not be a final solution. Banes thinks that in the long term the bodies legally charged with the task should be responsible for maintenance. At the same time municipal maintenance is a way to create employment opportunities.

Chris Banes, a municipal engineer from Great Britain, an outstanding professional experience in upgrading slums in Asia and Africa. He was involved in urban projects in Indonesia, Malaysia, India, Pakistan, Nepal, Nigeria, Malawi, Tanzania, Zambia, Zimbabwe, Ethiopia, South Africa, Swaziland and Ghana.

Source: Chavez, Gattoni and Zipperer, 2000: 10

Kampung Improvement Program (KIP) is a community based development effort in which the community plans, implements and monitors the project based on its needs and priorities, indeed with the support of local government and supporting institutions. These programmes are concerned with upgrading the physical infrastructure: roads, footpaths, drainage canals, water supply, sanitation, solid waste disposal, schools and clinics. Kampungs are the informal or unplanned, usually crowded and slummy, settlements where most Indonesian urban live. Governor Ali Sadikin initiated KIP in Jakarta in 1969. Through the World Bank loan, the programme has upgraded some 7,700 hectares of kampung and improved conditions for some three million people. Since 1976, a similar programme has been operating in Surabaya. Now, KIP has been implemented in many cities in a country and that according to Chris Banes is considered to be the world's largest urban programs and ranks among the best urban poverty relief efforts ever (see Box 5).

Kecamatan Development Project (KDP) was started in 1996, the last years of The Soeharto's Administration. By 2003 the program was operational in $25 \%$ of villages in the entire country. It is now in its third phase and has been implemented in over 28,000 villages throughout the country. The centerpiece of the KDP is the sub-district council, consisting of the government-appointed sub-district administrator and elected representatives of the villages within the sub-district.

To prevent from corruption, the initial regulations attached to the loans focused on procedures that would help ensure transparency in the decision-making process and formal accounting for the use of project funds. For instance, project regulation required the establishment of a formal monitoring and complaints mechanism by which community member could file a complaint directly with the national KDP secretariat via a special post office box. Local communities implementing projects funded through the KDP were required to contract with independent NGOs to monitor and report on implementation. The KDP rules also made provision for crossaudits between sub-districts, the publication of audit reports, and the public costing of project budgets. To ensure a high level of community participation in the decision making process, any village within the sub-district could submit a funding proposal to the council, provided that the submission conformed to the World Bank regulations. Each proposal was required 
to be presented to the sub-district council by a village delegation composed of at least two women and one man, each of whom had to be elected by secret ballots cast by all eligible members of the village (Rawski, 2006: 929).

Urban Poverty Alleviation Program (UPAP) or Program Penanggulangan Kemiskinan Perkotaan (P2KP) is a community-based program in urban areas that applies integrative approach by improving physical, economic, and social capacities (Tridaya) of urban poor communities. First, this program attempts to eradicate poverty through community empowerment by generating collective actions among community members. The members are advocated to commit in a collective learning process through self-mapping, the establishment of Badan Keswadayaan Masyarakat (BKM), and utilization of Bantuan Langsung Masyarakat (BLM). These processes may create collective awareness and constructive knowledge, attitude, values and behavior to make them release from poverty.

Second, UPAP integrate three aspects of empowerment-physical, economic, and social-in a concept called Tridaya. Such empowerment efforts attempt to build a new culture-a new way of thinking, attitude, and behavior-of the poor in dealing with poverty issues. In other words, poverty alleviation efforts do not only rely on the availability of economic resources in the form of the availability of rotated funds for the poor families, but more importantly the institutionalization of local consensus as foundation for the rise of partnership among community members. UPAP attempts to utilize and empower social capital as local wisdom to eradicate poverty.

\section{Box 6 Evaluation of Urban Poverty Alleviation Program (UPAP)}

Center for Population and Policy Studies in 2005 carried out an evaluation study to evaluate the implementation of UPAP in 12 districts/municipalities: Pandeglang, Cirebon, and Bantul Districts, Tangerang, Center Jakarta, East Jakarta, Bandung, Tegal, Semarang, Yogyakarta, Surabaya, and Malang Municipalities.

This study found that UPAP implementation in targeted kelurahan has shown a dynamic interaction and learning process among local stakeholders. There is an improvement of community members' participation on the formulation of poverty reduction programs. They involve in mapping the local capacity and in formulating Middle Term Development of poverty alleviation program. There is strong evidence that a collaborative learning process to formulate and voice the community needs works in this instance.

The process to choose the coordinator of BKM is done transparently and democratically. However the community members tend to choose local elites which are popular or come from better social and economic status. The poor do not have enough courage to nominate or to be nominated as a coordinator.

They realize that the purpose of establishing BKM is as a tool to facilitate the development of economic productive efforts collaboratively; it also an instrument to learn how to organize, develop self-capacity and empowerment of groups. Yet, their concentration remains on the rotation of fund aids, not on the capacity to develop collaborative and integrated planning for improving their productive activities.

The program implementation on the improvement of physical facilities is the most successful one. The program is able to generate residents' participation either financial as well as social supports. But, still very few efforts have been made to create economic activities that can improve job opportunities among the KSM members, particularly the marginalized or unemployed group. The least success is on social aspect of empowerment. The scale of assistance if not enough to the reduce number of poor people significantly and self-sufficiency has not also well developed.

Source: CPPS UGM, 2007: 55-56). 
Third, the empowerment program offered by UPAP is treated as a community learning process and will strengthen the critical consciousness of the community. This is not a short term of instant poverty alleviation program; rather it needs long term and sustainable processes. This program avoids the use of charity approach in helping the poor. The fund provided by the program is used for productive activities and stimulants to make the poor more powerful, developed, and prosper together with other community members. But such ideal goals are not easy to accomplish. Studies by CPPS UGM provide a picture on how this program works in the fields (see Box 6).

\section{Civic Engagement in Public Services}

Good governance requires the state capacity to deliver good public services (Anderson, 1999; Batley, 2004; Andrews \& Shah, 2003). In the meantime, the quality of public services in Indonesia is still far from

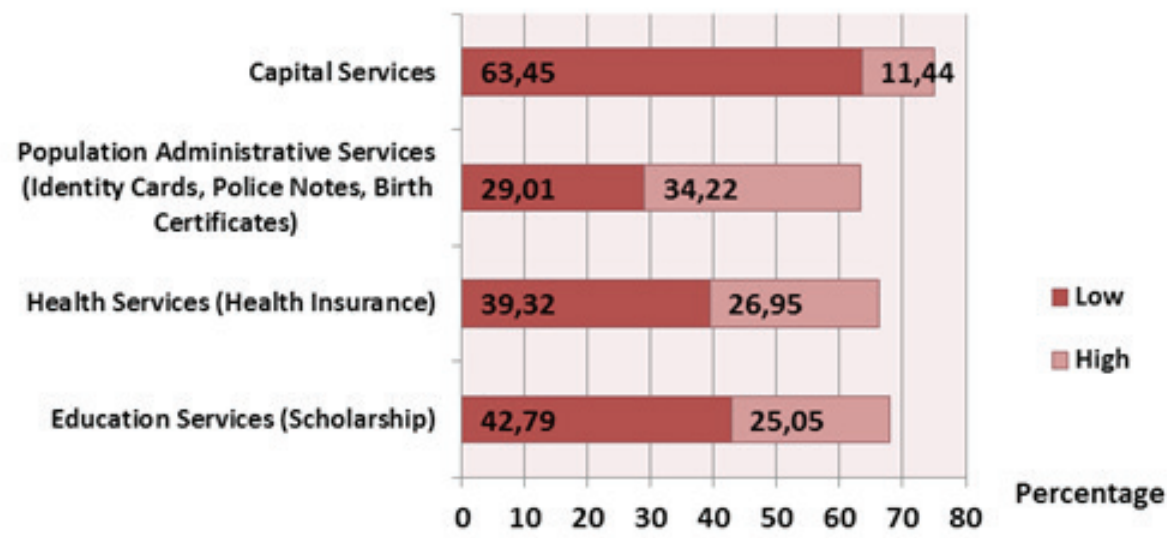

Source: CPPS UGM (2006), Governance Assessment Survey

Graphic 7 Societal Perception on Public Services

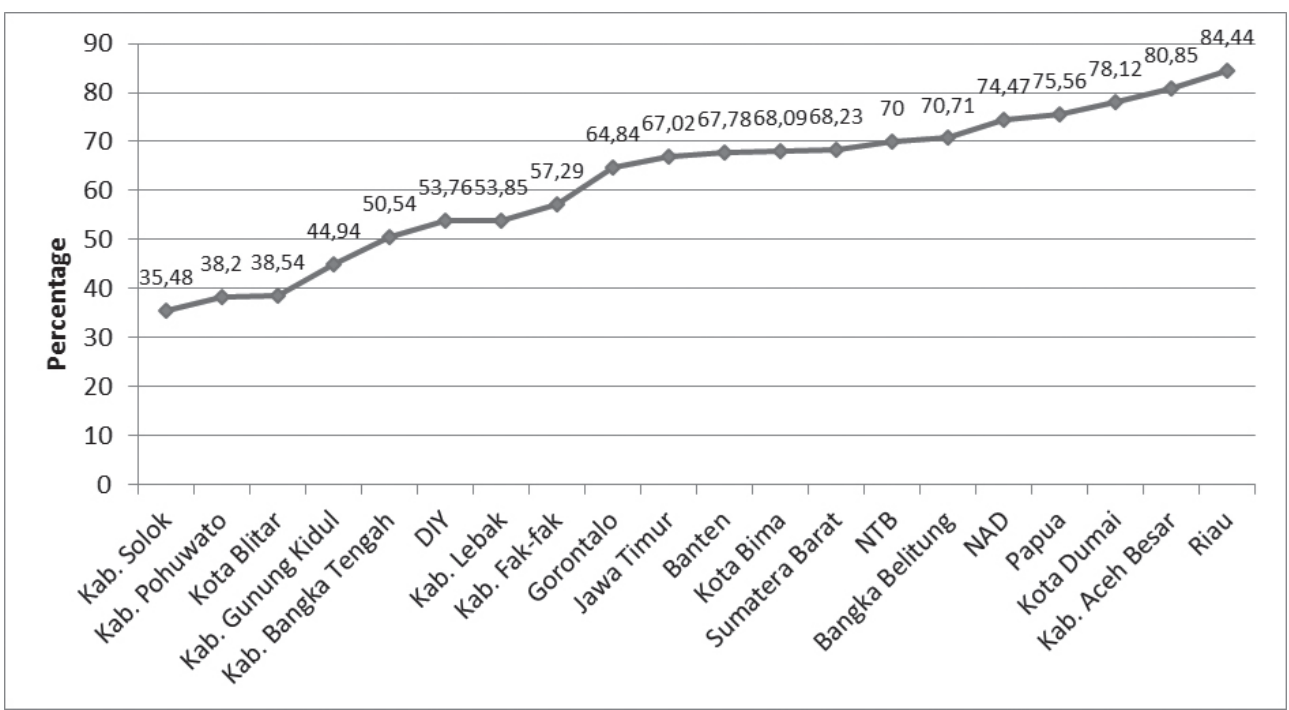

Source: CPPS UGM (2006), Governance Assessment Survey

Graphic 8 Giving 'Extra Money’ to Obtain Public Services Judged as Common or Fair 
the expectation. Political and Economic Risk Consultancy (PERC) put Indonesia as a country with worst bureaucracy in Asia. In Thailand businessmen should go through four types of procedures and take around a week to accomplish; in Vietnam seven procedures for average 50 days; while in Indonesia, businessmen should undergo 12 procedures for 151 days (Kumorotomo, 2007: 2).

Data of Governance Assessment Survey by CPPS UGM in 2006 in ten provinces of Indonesia shows that societal perception on public services is quite bad, because (1) the services has not pro-people or pro-poor yet and (2) bureaucratic corruption has spread down to the operational level of public services in the forms of bribery. Graphic 7 show the low access of the poor to receive public services, and Graphic 8 demonstrate bribery practices in a number of districts/municipalities.

\section{Citizen Report Card}

One of the solutions to make public service provision meet the societal needs and provide more access to the poor is by involving societies in the service delivery processes. There are a number of methods to engage citizens in public service provision. One of them is citizen report card. CRC is formal, quantitative surveys of client satisfaction with public services have been conducted by nongovernmental organizations (NGOs) in several Indian cities. It was initiated in Bangalore, India, then it was replicated in other Indian cities (such as Mumbai and Calcutta) and worldwide (e.g., Ukraine, the Philippines, and Washington, DC). A number of local governments in Indonesia have also adopted this new method, such as Lebak, Magelang and Ngawi Districts, Bandung and Semarang Municipalities, East java Province.

The surveys generate "report cards" on the perceived quality and responsiveness of a range of urban services. They are used to put pressure on elected officials by demonstrating the extent of public dissatisfaction and areas in need of improvement, that hope that this will result in greater responsiveness on the part of public servants responsible for services. The surveys are also use to educate the media, the public interest groups, and citizens (Ackerman, 2005: 14).

The report card has seven phases: (1) identification of scope, actors, and purpose; (2) design of questionnaires; (3) sampling; (4) execution of survey; (5) data analysis; (6) dissemination; and (7) institutionalization. The unit analysis is the household or individual, and the method relies on stratified sampling to ensure that the data from a survey questionnaire are representative of the underlying population. The intent is to uncover problem areas in relation to service delivery. The dimensions probed include access, quality, affordability, willingness to pay, staff behavior, efficiency, reliability, adequacy of supplies, and overall user satisfaction (Arroyo \& Sirker, 2005: 13).

Thereportcard methodologywas developed in order to expose government agencies to the consumer feedback they are lacking. The guiding idea behind the methodology is to introduce market type initiatives to the functioning of government. Through the report card methodology, agencies can see how their performance changes from year to year as well as compare themselves to other agencies in a comparative, competitive dynamic similar to that imposed by the market. And all of this occurs through the independent action of civil society and the power of information.

\section{Community Score Card (CSC)}

Close to CRC is Community Score Card (CSC). CSC permits tracking inputs and expenditures, monitoring the quality of services and projects, generating benchmark performance criteria that can be used in 
resource allocation and budget decisions, comparing performance across facilities and districts, and generating a direct feedback mechanism between providers and users. The community score card process is a community-based monitoring tool that uses the community as its unit of analysis and focuses on monitoring at the local or facility level. It employs a methodology for soliciting users' perceptions on quality, efficiency, and transparency, similar to that used by citizen report cards. In Sri Lanka, the Community Development and Livelihood Improvement Project apply this model. The project is designed to target poor communities in the project area and improve their livelihood and quality of life by enabling them to build accountable institutions and to manage sustainable investments. The project uses CSC to list the criteria for evaluating the performance of village organizations, and communities grade their performance every month or six months. In addition, the village organizations evaluate themselves and present their findings to the villages (Arroyo \& Sirker, 2005: 14).

\section{Continues Improvement and Benchmarking $(C / B)$}

Continues Improvement is a systematic method to improve service delivery for access, timeliness, quality, cost, community satisfaction and affordability while is comparing services with others to improve your own service delivery. Benchmarking is done by comparing performance and sharing information about service practices, to find the 'best' practices and increase service standards. Continues Improvement and Benchmarking have enabled service delivery improvements in many organizations, government and private, in numerous countries around the world.

The Asian Development Bank (ADB), the Asian Development Bank Institute (ADBI), and the German Agency for Technical Development (GTZ) funded a Regional Technical Assistance program (RETA) to test the use of CIB techniques as a means of improving the delivery of municipal services. This RETA also intended to create an active network of municipalities to exchange information on successful change efforts and good practices.

This project was tested in ten cities across Asia, including Pakistan, India, Sri Lanka, China, Malaysia, the Philippines and Indonesia. One of the pilots in Indonesia is collaboration between CPPS UGM and two local governments; a range of services in these cities was improved to verify that the CIB techniques would yield results. The improved services included: solid waste collection, customer service counter and complaint handling, property tax assessment and collection, venue parking, and street vendors. CPPS UGM has successfully piloted CIB in collaboration with two local governments, Sleman District and Yogyakarta Municipality on solid waste collection (ADBI, 2005).

In a number of countries The CRC method is combined with another participatory method, called Continues Improvement Benchmarking (CIB). The Center for Population and Policy Studies, Universitas Gadjah Mada advocated the application of these new methods in Yogyakarta Municipality and Sleman Regency in 2006. CRC is a survey of public and social services that affect the poor and give service recipients and opportunity to grade the agencies that provide the services, while $\mathrm{CIB}$ is a continues process in which a service provision unit seek to challenge of their practices by comparing the practice it does with the others' practices. In this instance, the organizations evaluate various aspects of their processes in relation to best practice, usually within their own sector. This then allows organizations to develop plans on how to make improvements or adopt best practice, usually with the aim of increasing some aspect of performance. 


\section{Muhadjir Darwin}

\section{Citizen Charter}

Another participatory model of service provision, which is now widely adopted in Indonesia, is Citizen's Charter (CC). CC is the model of service delivery processes, which put the clients and society at large as the proactive stakeholders. The charter expresses the understanding between citizens and a public service provider on the quantity and quality of services citizens receive in exchange for their taxes. It is a written, voluntary declaration by a service provider about its service standards, accessibility, transparency, and accountability. The Citizen's Charter was apparently a British political initiative launched by the then Prime Minister, John Major, on 22 July 1991. It aimed to improve public services in the UK by (1) making administration accountable and citizen friendly. Ensuring transparency and the right to information; (2) taking measures to cleanse and motivate civil service; and (3) adopting a stakeholder approach (Wikipedia, the free encyclopedia).

$\mathrm{CC}$ is not only applied in Anglo-Saxon countries (United Kingdom and Irlandia), but also being an important part of The Charter of Fundamental Rights in European Union. Nowadays CC has been applied worldwide, including in Indonesia. The first initiation of $\mathrm{CC}$ in the country is in Yogyakarta and Blitar Municipalities and in Semarang District. These three local governments collaborate with CPPS UGM to pilot this new method. Each local area applies this method in a certain sector of public service. Blitar focuses on public health services; Semarang applies in certain sub-districts on Residents' Identification Card (KTP), Hindrance Ordinance, Business Location Permits) while Yogyakarta choose to focus on Birth Certificate services. Nowadays we can name more local governments that have applied CC, such as Bogor Municipality, Mataram Municipality, Lemboto District, Binjai Municipality, Asahan District and Lamongan District (Kumorotomo, 2007: 8).
The pilot projects in several districts/ municipalities have successfully transformed the paradigm of public service provision into a new culture of serving people. CPPS UGM reports that its pilot project has improved customers' awareness of their rights and responsibilities in the process of service delivery. The mindset of the providers has also changes to more clients oriented and leaves their arrogant attitude. The high concern given by regents and mayors in supporting the institutionalization of the citizens' charter has in fact accelerated the process change. Kumorotomo also reported positive impacts of the $\mathrm{CC}$ adoption. The implementation of CC in Bogor has improved the effectiveness of population services. The use of CC on garbage services in Mataram is also considered effective.

\section{Conclusion}

We are in the era of democracy, governance and decentralization in which citizens' participation is an unavoidable requirement to make the systems work effectively and as a strategic tool to assure that local development efforts will meet the citizens' demand and yield better results for all citizens, particularly the poor. To develop an accountable local development, there are two basic approaches available to adopt at the same time. From the supply side is local governance reform to restructure local government institutions and mechanisms, to reform local regulations as a legal basis to develop transparent and accountable local governments, to develop participatory model of local development planning, budgeting, and public service delivery mechanisms. In the meantime, from the demand side is to empower citizens through the improvement of citizens' capacity and opportunity to participate in the whole processes of local development. To make such integrative local development, collaboration among local governance- 
local government, business sector, and civil society -is undoubtedly needed.

There are strong evidences that Indonesia has been on the right tract to develop participatory models of local development. Many local governments have enacted new regulations that give legal foundation to reform the local development mechanisms. Participatory mechanisms have also been made in planning, budgeting and service provision. In the last decade of implementing this new model of development we note a lot of success story as well as fail story. We should use successful practices as a benchmark for us to learn and follow, while the fail practice is also a good learning for others to avoid. But, the point is that we should not make some of those failures as a reason to leave the democratic and decentralist model the nation has chosen. Indonesia has been on the right tract and there is no reason to turn the clock back to the obsolete centralist and authoritarian system. What we have to do is to continue the process, to learn wisely and properly either the successes as well as from the failures we made, so that we are able to build better efforts in order to achieve better future for all.

\section{References}

Ackerman, John M. 2005. Social Accountability in the Public Sector: A Conceptual Discussion and Learning Module. World Bank Institute.

ADB (Asian Development Bank). 2005. "Republic of Indonesia: Pro-Poor Planning and Budgeting (Co-financed by the Government of the United Kingdom)," Technical Assistance Report, pp. 2.

ADBI (Asian Development Bank Institute). 2005. Continuous Improvement and Benchmarking Handbook.

Andersson, Vibeke 1999. "Popular Participation in Bolivia: Does the law
"Participation Popular" Secure Participation of the Rural Bolivian Population", $C D R$ Working Paper 99.6, October.

Andrews, Matthew and Anwar Shah. 2003. Voice and Local Governance in the Developing World: What is done, to what effect, and why? World Bank.

Arroyo, Dennis, and Karen Sirker. 2005. Stocktaking of Social Accountability Initiatives in the Asia and Pacific Region. Washington, DC: Community Empowerment and Social Inclusion (CESI), World Bank.

Batley, Richard. 2004. "The Politics of Service Delivery Reform." Development and Change, 35, 1, January.

Bichal, Johnston. 2005. "A Joined-up Approach to User Participation in Public Services: Strengthening the 'Participation Chain", Social Policy \& Administration. Vol. 39, No.3, June.

BKBK and SMERU. 2001. Basic Information Package for Poverty Alleviation.

CPPS UGM (Center for Population and Policy Studies, Universitas Gadjah Mada). 2003. The Institutionalization of Citizens' Charter on Public Service in Yogyakarta Municipality, Semarang District and Blitar Municipality. Yogyakarta: CPPS UGM and Ford Foundation.

CPPS UGM (Center for Population and Policy Studies, Universitas Gadjah Mada). 2007. Building Poverty Alleviation through Society Empowerment.

Chavez, Roberto, George Gattoni, and Melanie Zipperer. 2000. "INDONESIA The Kampung Improvement Program (KIP) - Successful Upgrading with Local Commitment Chris Banes Talks About His Experiences". Urban Services to the Poor, Thematic Group, World Bank Group, January 12.

Darwin, Muhadjir. 2005. Humanizing People: Poverty Alleviation as a Mainstream of Development. Yogyakarta: Benang Merah. 
Department of Economic and Social Affairs (DESA), Division for Public Administration and Development Management, United Nations. 2005. Citizen Participation and Pro-Poor Budgeting. New York.

Eko, Sutoro. 2008. Pro-poor Budgeting: The NewPolitics of LocalBudgeting Reformation for Poverty Alleviation - Working paper IRE: Yogyakarta, Indonesia.

Gillespie, Stuart. 2004. "Scaling Up Community Driven Development: A Synthesis of Experience". FCND Discussion Paper No. 181. Washington D.C.: International Food Policy Research Institute (IFPRI).

Hale, Thomas N. 2008. "Transparency, Accountability and Global Governance", Global Governance, 14, Lynne Reinner Publishers.

Louis Helling, Rodgigo Serraro, David Warren. 2005. "Linking Community Empowerment, Decentralized Governance, and Public Service Provision Through a Local Development Framework. Community Driven Development and Social Protection", The World Bank, SP Discussion Paper, No.0535, September.

Malena, Carmen, ReinerForster, and Janmejay Singh. 2004. "Social Accountability: An Introduction to the Concept and Emerging Practice." Social Development Papers, Participation and Civic Engagement. Paper No. 76, World Bank, December,

Menko Kesra (The Coordinating Minister for Social Welfare). 2005. the National Strategies for Poverty Alleviation. Jakarta.

MOCS (Montana Office of Community Service). Montana's Official State Website. http://mt.gov/.

Narayan, D and P. Petesch (eds.). 2002. Voices of the Poor: From many lands. New York: World Bank and Oxford University Press.

Pattinasarani, Daan and Candra Surya. 2007. "Transparency, Participation and Public
Services in P2TPD regencies, Findings GDS 2006", Jakarta: World Bank, DSF Working Paper, December.

Rawski, Frederick. 2006. "World Bank Community Driven Development Programming in Indonesia and East Timor: Implications for The Study of Global Administrative Law," IIserver05/productn। NYII37-4INY1407.txt, 1 November.

S2-PLOD (Master Program on Local Politics and Local Autonomy), Gadjah Mada Univeristy. 2008. Public Involvement in Decentralization of Governance: A Study on Problems, Dynamics, and the Prospects of Civil Society Organizations in Indonesia. Collaboration among PLOD-UGM with BRIDGE, Bappenas, and UNDP.

Schedler, Andreas. 1999. "Conceptualizing Accountability," in Andreas Schedler, Larry Diamond, Marc Plattner, (eds.), The Self Restraining State: power and Accountability in New Democracies, pp.13.

Simmons, Richard and Johnston Bichal. 2005. "A Joined-upApproach to User Participation in Public Services: Strengthening the 'Participation Chain'", in Social Policy \& Administration. Vol. 39, No.3, June.

Stalker, Peter and Satish Mishra. 2003. "The Right to Development in Indonesia", Working Paper Series, No.03/01. Jakarta: UNSFIR.

Suhirman. 2005. "The New Trends and Practice in Societal Members' Participation in Indonesia", Executive Board of Societal Participation Forum (FPPM).

UNDP. 2004. The 2004 World Development Report: Making Service Work for the Poor.

United Nations. 2005. Citizen Participation and Pro-poor Budgeting, Department of Economic and Social Affairs Division for Public Administration and Development Management. United Nations: New York.

Wikipedia, https://en.wikipedia.org/wiki/ Wikipedia:Free_encyclopedia. 